\title{
The Faizrakhmanisty: The Islamic Sect as a Social Problem in Russia
}

\author{
Kaarina Aitamurto
}

In 2012, news about a police raid on the premises of an Islamic group named the Faizrakhmanisty (after its leader and initiator, Faizrakhman Sattarov) was reported across the Russian media. ${ }^{1}$ During the raid, it was said, the police found tens of children living underground in unsanitary conditions. Different versions of the story of this sect, ${ }^{2}$ which was said to be waiting for the end of the world in an isolated compound, spread rapidly throughout not only the Russian media, but also the Western media. The story of the Faizrakhmanisty brings together several topics that have been prominent in the recent political attitude toward Islam in Russia and representations of Islam in the Russian media. This chapter argues, first, that the term 'sect' is used frequently as an evaluative concept in the construction of certain Islamic organizations or phenomena in the Russian media. Second, it is suggested that the idea of the 'totalitarian sect', used in particular by 'experts' committed to the anti-cult stance to combat non-institutionalised or 'non-traditional' forms of Islam, is often introduced in the media to guide interpretations of Islam-related content.

The chapter begins with a discussion about Islam, religious freedom, and media representations of religion in Russia. The first part of the analysis focuses on the ways that the term 'sect' is used in the Russian media by focusing on four very different phenomena that have been labeled as Islamic sects: Wahhābism, Hizb ut-Tahrir, Nurdzhular, and the National Organization of Russian Muslims (NORM). The second part of the analysis examines the case of the Faizrakhmanisty and its coverage in the media.

1 I wish to thank Renat Bekkin for his insightful and helpful comments on the earlier version of this chapter. This chapter reproduces some of the material published in K. Aitamurto, 2018, "The Faizrakhmanisty: The Islamic Sect as a Social Problem in Russia," Alternative Spirituality and Religion Review, 9:2, 165-189.

2 In this article, I use the term "sect" as it appears in the media and scholarly analyses of the Faizrakhmanisty and other Islamic groups, without going into debates on the theoretical basis or relevance of the term in relation to these groups. 
In contemporary Russia, the word 'sect' has even more negative connotations than in Western Europe or North America. The reason for this can be found in the social history of the 199os, when the idea that new religious movements, often referred to simply as 'sects', were socially dangerous phenomena gained ground. This shift toward more authoritarian and conservative religious politics began soon after the post-Soviet religious revival that followed the introduction of an extremely liberal religious freedom law in 1990. One aspect of this religious renaissance was an upsurge in new religions, religious influences, and foreign missionaries arriving in Russia. These elements upset the Russian Orthodox Church (ROC) in particular. It claimed that missionaries were acting impudently in relation to Russia's own religious traditions. The ROC appealed to its disadvantaged position in comparison with Western-originated Christian organizations here; while the ROC was still recuperating from the material and educational damage caused during the Soviet era, many of its competitors had much more solid financial bases. The Roc capitalised on the claim that the Soviet period had alienated Russians from their own religious heritage, making them religiously illiterate and therefore vulnerable to all kind of religious propaganda (Fagan 2013: 53-62).

Some challenges to new and foreign religion also came from below, although they tended to have been designed carefully by the ROC itself or by social circles close to it. Western anti-sect activists and scholars of religion who held negative attitudes toward such groups (but hardly represented the mainstream with regard to academic views on new religions) were invited to Russia. Some Orthodox Christian activists, such as Alexander Dvorkin, aimed to introduce the new discipline of 'sectology' (sektovedenie) and the title 'scholar of sects' (sektoved) to academic circles (Baran 2006). Although sectology was mostly rejected by the academy, expressions like 'totalitarian sect' and 'destructive sect' became established in the media, where the so-called 'scholars of sects' were presented as authoritative experts on the development of sectarianism in Russia. The common definition put forth by the press indicated that a 'sect' was an organization controlled by a power-hungry leader who brainwashed people and dissolved families for his/her own financial benefit. As a consequence of the religious developments in the country at this time, the new, stricter Law on Freedom of Conscience and Religious Associations was introduced in 1997. Since then, some amendments have been made to impose still further limits on the activities of minority religions (Shterin and Richardson 2000; Fagan 2013: 62-74). 
Although the 1997 law did not mention any religions in particular, it has been referred to surprisingly widely in discussions and policies as legitimizing the four 'traditional religions' of Russia: Orthodox Christianity, Islam, Judaism, and Buddhism. Unsurprisingly, then, many official Islamic organizations and leaders joined the Orthodox Christians in demanding stricter control of new and Western-originated religions. At the same time, however, Islam has not been overlooked as a possible source of societal problems. In post-Soviet Russia, Islamic organizations faced similar challenges to the Roc: an insufficient amount of religious buildings, many of which were in a bad condition; a shortage of religious literature; a lack of trained religious professionals. In such a dire situation, aid from Islamic countries was crucial for Russian Muslims, in terms of both providing education for future imams and supporting the building of new mosques and madrasas. As a result, the perceived influence of foreign Islam on Russia caused concern over the radicalization of Muslims. This tendency was reinforced by the rise of negative attitudes toward Islam than began after $9 / 11$ and certain terrorist actions in Russia (Verkhovsky 2010: 30; Kemper 2012: 120).

The idea of the need to control Islamic religiosity and Muslims in Russia can be traced back, however, to Catherine the Great. Ivan the Terrible's conquest of Kazan in $155^{2}$ had given Russia's crown a substantial number of Muslim subjects. Catherine the Great was the first ruler to grant some (albeit limited) religious rights to them, including the right to build new mosques and to perform hajj. Although the liberal philosophy of the Enlightenment undoubtedly influenced Catherine's political line, another significant motivation in her politics concerning the Muslim minority was to guarantee the loyalty of her subjects. In addition to providing them with a new level of freedom, Catherine decided to create a single, centralised, hierarchical organization, which could act as a mediator between the state and the Muslim community, as well as having control over the latter. Thus, the Orenburg Mohammedian Spiritual Assembly was founded and was based on the Christian tradition of hierarchical organizations - a concept quite alien in Islam. Over the centuries, the name of this organization changed several times, but the centralised structure was preserved until the end of Soviet times (Crews 2009: 33, 49-53).

At the end of the Soviet period, four Muftiates governed the Central Asia/ Kazakhstan, South Caucasus, North Caucasus, and European Russia/Siberia areas, respectively. In the 199os, religious liberation, coupled with dissatisfaction with the old, Soviet-time religious authorities, led to the burgeoning of new religious communities, as well as divides within existing organizations (Bukharaev 1996; Yemianova 2003: 140, 143-7). Nevertheless, a substantial proportion of the Islamic religious establishment continued to express a 
preference for having a single organization that could represent all Russian Muslims. It was felt that a unified voice would allow Muslims to be heard better in society and to be more efficient in controlling the radicalization of the youth. Admittedly, internal power struggles between Muslim organizations challenged this aim, discrediting the community in the eyes of both Muslims and non-Muslims, thus leading to further social divisions. Despite such consequences, in the aspiration to centralise Islamic activity, one can discern a wish to monopolise Islam in Russia once again. Furthermore, the idea of centralization reproduces the evaluative dichotomies of 'traditional' and 'nontraditional' or 'official' and 'non-official' religiosity (Aitamurto 2015).

It should be noted here that the policies put in place to protect 'traditional religions' refer mainly to certain institutions that represent those religions. Orthodox Christian Churches other than the Roc, for example, have also faced difficulties or even oppression, but have had little protection. In a similar vein, newer Islamic organizations have often been refused the right to become registered as religious groups. Instead, their premises have faced raids and even closure. Indeed, the situation is more complex in the Islamic case than in the Orthodox Christian one. The preferred Islamic organization varies by region, and there are constant struggles to adopt the position of most powerful organization. For example, almost all of the mosques in Moscow are controlled by the Religious Board of Muslims of the Russian Federation (Dukhovnoe Upravlenie Musul'man Rossiiskoi Federatsii, or DUMRF), a group which has sought to extend its control further but has had difficulty in establishing its activities in places like St Petersburg (Aitamurto and Gaidukov 2018).

The discussion about certain forms of Islam posing a social problem has mainly revolved around the concepts of 'official' and 'unofficial Islam' (and, later, 'traditional' and 'non-traditional' Islam-see Makarov and Mukhametshin 2003; Aitamurto 2015). Ironically, some of the Islamic traditions that were seen as the main reference points for 'unofficial Islam' in Soviet times are now accepted as authentic, local, traditional Islam; this is the case, for instance, with Șūism in Central Asia and the North Caucasus. The category into which a religious organization is placed can have significant consequences for its social position because authorities will lend official support to traditional Islam, while working to prevent the growth of non-traditional Islam because it is seen as problematic. The term 'traditional Islam' has been criticised by some Russian scholars and Muslims (Malashenko 2013; Mukhametov 2015) for its vagueness and normativity, but it is still used frequently by politicians, authorities, and the most prominent Islamic leaders to distinguish 'good' Islam from its 'bad' counterpart. There are, indeed, countless ways to interpret this concept; most often, however, 'traditional Islam' is conceived as including 
features like loyalty to the Russian state and a long history of operating in a given area. This means that types of Islam considered traditional in certain parts of Russia are seen as non-traditional in others; the Shāfi'i madhhab, for example, is viewed as non-traditional in Tatarstan, Moscow, and St. Petersburg, despite being accepted as traditional in North Caucasus. Likewise, in 2011, the Spiritual Board of the Muslims of Tatarstan (Dukhovnoe Upravlenie Musul'man Respubliki Tatarstan, or DUMRT) announced that all imams of the republic should base their teaching on the Hanafi madhhab, In addition, in 2012, the President of the Republic of Tatarstan, Rustam Minnihanov, signed a law stating that imams who had studied abroad must have their diplomas confirmed in Russia before being allowed to work in local mosques, thus posing a risk to the survival of non-traditional Islamic groups. As eminent Islam scholar Alexey Malashenko points out, such restrictions can drive unofficial religious organizations underground where they are more difficult to be controlled and in a greater risk to get radicalised (Andrukhaeva 2012).

Surprisingly, given the prevalence of conversations about 'sects' in the Russian media, the phrase 'Islamic sect' is seldom used. A quick survey of the use of this combination of words in the Russian media database Integrum between 2000 and 2015 reveals that it usually (but not always) refers to foreign groups, such as Boko Haram. Sometimes, Russian groups such as Hizb ut-Tahrir, Nurcular (Nurdzhular in Russian), and the Wahhābists are also labeled as such, as is militant Islam in general. Journalists, politicians, and Muslim leaders seem, at times, to issue warnings about Islamic sects in general terms - to support calls for tighter control of the religious behavior of Muslims, for example.

In the book on Islamic sects published by Mir Islama and recommended for use in religious education, author Murat Mamirgov (2007: 6) writes that sects have brought no additional value to Islam; rather, they have only caused division and discordance within the umma. His views represent a widely shared attitude toward sects among Russian Muslims. According to the Deputy Director of the Foundation for the Support of Islamic Culture, Science, and Education, Ali Vyacheslav Polosin, the undesirable features of sects include the existence of religious innovations (bid'a) and 'exclusive truth' claims. Among his examples of sects, Polosin mentions Salafism. According to him, a sect can never become a religion and is typically "bloody and criminal" (Khizrieva 2011). Less condemnatory attitudes toward sectarianism can also be found in Russia. An eminent scholar of Islam, Aleksandr Ignatenko (2003), defends the concept of the Islamic sect, seeing it as a natural part of the religion. He stresses that for Muslims and scholars of Islam, such developments do not have the negative connotations that are associated with the emergence of sects in other religions-especially in Christianity. The concept of the 'totalitarian sect' has 
been used, however, by Muslim clerics; the head of the Central Spiritual Board of Muslims of Russia (Tsentral'noe Dukhovnoe Upravlenie Musul'man Rossii, or TsDUM), Talgat Tadjuddin, has referred to the danger posed by 'totalitarian sects' within the Russian umma (Crews 2014).

\section{The Study of Islam and Anti-Extremist Legislation}

In Soviet times, the study of Islam was focused mostly on two topics: 1) the role of Islam in the politics of foreign countries and 2) classic Islamic literature and culture. There was hardly any research conducted on Muslims or Islamic religiosity within the USSR. In contemporary Russia, a new generation of scholars has engaged in the ethnographic and sociological study of the Muslim communities of the country, but the number of specialists in this field is still relatively modest. There are also individuals working at various think tanks or institutions and are considered by the public to be specialists in Islam (Kovalskaya 2017). Some of them have clearly indicated preferences for certain organizations within the Russian umma - or have even displayed political ambitions. Of course, these matters influence their interpretations of Islam. One of the best-known examples of such an expert is Roman Silantyev, who has also been a member of the prestigious Inter-religious Council of Russia and works in the Department of External Affairs at the Moscow Patriarchate. In his writings, Silantyev expresses his sympathies for the TsDUM, which can be considered more compliant, where the demands of the Roc are concerned. Moreover, Silantyev does not hesitate to make accusations of extremism and radicalism against the TsDUM's main rival, the DUMRF (on Silantyev, see Kovalskaya 2017: 143-146). According to Roland Dannreuther (2010:18), Silantyev represents the not-so-rare tendency of Islam scholars in Russia to "entrench, rather than to problematise the dualistic bifurcation between foreign radicalism and moderate traditional Russian Islam" and to "view political Islam as primarily an ideological threat and something that needs to be eliminated rather than contained." As a consequence, the titles of 'expert' or 'scholar' of Islam can be considered somewhat dubious in the Russian context. Indeed, some of the work of experts like Silantyev can be thought of as bordering on Islamophobia.

Scholarly discussions about religious radicalism have gained special importance in Russia, where the authorities have tightened up procedures regarding religious 'extremism' significantly in recent years. Now, suspicions about extremist activity can be fatal to religious organizations. The first anti-extremist law was implemented in 2002 and, since then, several new statutes have been introduced. From the outset, however, these anti-extremist laws have been 
criticised for their vague wording, which allows a wide range of activities to be labeled 'extremist' and prohibited. Where religiosity is concerned, one of the most problematic aspects is the ban on preaching 'religious superiority'. Not surprisingly, this means that religious publications account for a very large proportion of the list of banned literature in Russia (Ledovskikh 2013; Fagan 2013: 158-70).

The labeling of a religious organization as a 'sect' in the media often has tangible consequences for the organization in question. Geraldine Fagan draws a parallel between the Soviet-time media campaigns against some enemies that led to administrative measures against them and the current branding of religious communities as sects. She suggests that some of these media campaigns are 'ordered' by local authorities or representatives of the ROC (Fagan 2013: 99-100). Vladimir Lukin, who served as the Human Rights Commissioner of Russia from 2004 to 2014, has commented that the policy for passing verdicts of extremism often involves the "misguided personal opinions of experts, who have no training in the study of religion, who are not basing their arguments on the scholarly literature of the study of religion, but on the accusatory 'sectological' directories. In these experts' statements about the activity of religious communities, the accusations of activity that is allegedly harmful to the moral, mental and physical health of their members and other citizens, are often unfounded and do not prove that these communities would have committed such offenses" (Smirnov 2008; see also Shterin \& Dubrovsky 2019).

This article does not seek to provide evidence regarding a link between media accusations of sectarianism and court verdicts of extremism, although such links certainly do appear in the published literature. However, an examination of the wide and indiscriminate usage of the term 'sect' in public discussions reveals that it is often utilised as a derogatory label through which certain forms of religiosity are discredited, rather than as a concept based on any scholarly understanding of the term. Next, I will discuss four very different organizations that are often referred to in the Russian media as sects.

\subsection{The Wahhäbists}

Geraldine Fagan argues that in the internal quarrels within the Russian umma, Wahhābism plays the same role as the 'totalitarian sect' does in public debates (Fagan 2013: 162). In Russia, the usage of the term 'Wahhābism' is broad, to say the least; it tends to be used, according to Alfrid K. Bustanov and Michael Kemper, to refer to "all Salafi trends in Islam, which are critical 
of the theological, legal and Șūi 'traditional' schools and brotherhoods in the country, and which are believed to have been 'imported' from the Arab world, Pakistan, Iran and Turkey" (Bustanov and Kemper 2013: 809).

In 1999, under an initiative driven by the local Muftiate, Wahhābism was banned in the Dagestan Republic of the Russian Federation. Similar laws were soon introduced in other southern republics, including Chechnya. There were also attempts to widen the ban to cover the whole Russian Federation. Scholar Aleksei Malashenko (2007, 34-5) recollects that some "experts from Moscow," including Malashenko himself, managed to convince the ruling elite that the ban would be senseless. It should be noted that, while President Putin (who probably did not wish to complicate foreign relations with Saudi Arabia) recommended that the word 'Wahhābism' should not be used as a synonym for radical or terrorist Islam back in 2006, its usage as such still continues in the media and at lower levels of the Russian Government (Fagan 2013: 161).

When I searched the media database Integrum for word combinations like 'sect Hizb [ut-Tahrir]', 'sect Nurdzhular', and 'sect N ORM', the largest number of hits came from the combination 'sect Wahhābism'. For example, an article in the newspaper Izvestiya, discussing politics in Saudi Arabia, provides its readers with a small amount of background information, which begins: "Wahhābism itself (which the other Muslims consider as a sect and its followers as heretics) was founded in the eighteenth century" (Yusin 2003). However, the number of hits for the word combination decreases over the ten-year period for which I performed the search. Correspondingly, in that time, a new topic 'sect IsIs', has begun to appear more frequently.

\subsection{Hizb ut-Tahrir}

A decision by the Highest Court of the Russian Federation in 2003 banned Hizb ut-Tahrir on the grounds of it being a terrorist organization aiming to eliminate non-Islamic governments, including those in Russia and the CIS countries. ${ }^{3}$ The director of the human rights and analytical center sova, Alexander Verkhovskii (2006), argues that although there were good grounds to ban Hizb ut-Tahrir for being extremist-including its incitement of religious and ethnic hatred, and its propagation of anti-Semitism in particular-the terrorism verdict was unsubstantiated. He reminds us that the organization does not call

3 Federal'nyi zakon "O Bor'be s terrorizmom," No. 130-FZ, 25 July 1998. The verdict. Reshenie Verkhovnogo Suda RF ot 14 Fevralya 2003 g. No. GKLI 03-116, Natsionanal'nyi antiterroristicheskii Komitet, https://web.archive.org/web/20160108040711/http://nac.gov.ru/content/ 3934.html. 
for terrorist action and that none of its members have been found guilty of inciting terrorism in Russia.

After the verdict, the human rights organization Memorial requested an analysis of Hizb ut-Tahrir's publications ${ }^{4}$ by the Head of the Spiritual Board of Muslims of Asiatic Russia, Nafigulla Ashirov. He concluded that the publications contained no calls for violence or the violent overthrow of the legal regime. After the statement was published on Memorial's website, the organization received a request from Moscow city prosecution to remove the material as it was potentially extremist. After a short legal battle, Memorial was forced to comply in 2005 (Fagan 2013: 157).

Human rights organizations have reported that questionable arrests and convictions have been made on the basis of membership in Hizb ut-Tahrir (Fagan 2013:157). Given that the Hizb ut-Tahrir has been denounced as a terrorist organization, its pleas for fair treatment are easy to disregard. In 2011, demonstrations were held against the mass arrest of Muslim activists in Tatarstan. The fact that members and symbols of Hizb ut-Tahrir were seen at these demonstrations led some authorities and Russian Islam specialists to brand the events radicals' attempts to achieve their own extremist goals, backed by "naïve human rights activists" (Suleimanov 2012).

Labeling Hizb ut-Tahrir as a sect is an integral part of the public campaigns mounted against it. The newspaper Moskovskii Komsomolets quotes the head of the DUMRT, Ravil Gainutdin: "For some, it may come as news but, nevertheless, Hizb ut-Tahrir is a typical sect. Namely a sect in which all the concepts of traditional Islam and the Qurān are presented in a distorted form" ("Rab Lampy" 2005). The same rhetoric can be found on some Islamic websites, especially those that are accused of being cover-up projects for anti-Islamic actors. For example, on 10 February 2014, Islam Today published the article "Hizb utTahrir: Islamic Party or a Misguided Sect?" which presented features like "religious marketing" and "aggressive missionary work and psychological pressure" as typical characteristics of a sect - and of Hizb ut-Tahrir in particular.

After the annexation of Crimea, the rights of the Crimean Tatars became an issue of concern. In comparison with Russia, religious politics in Ukraine are less prescribed. Although Russia promised to grant the Tatars the same privileges as other inhabitants of the area, soon after the annexation, raids began on mosques, madrasas, and Muslim homes. Several high-profile Islamic leaders have been forcibly deported or have left Russia of their own accord. The current leader of the Crimean Muftiate, Emirali Ablaev has remained silent

4 These five publications were selected because they have often been referred to in Russian court cases as evidence of the extremism of Hizb ut-Tahrir. 
about the oppression of Tatar people and religious activists in the peninsula. Instead, he has appealed to Russian authorities in his rivalry with other Islamic actors and organizations, accusing these of extremism and sectarianism. These accusations are used both as weapons in internal struggles within Crimean Muslim community and to show loyalty to Kremlin by vilifying Ukraine. As early as 2012, Ablaev, who was already then known of his pro-Russian stance, accused the Ukrainian authorities of oppressing the Crimean Tatars: "At the same time ... we can see within the Crimean procurator and the Ukrainian Secret Service a complete indifference toward the activity of radical, extremistterrorist sects: 'Hizb ut-Tahrir', Wahhābites, [members of] Al-Ahbash, takfirists and others. Not one of the appeals of the Spiritual Board of the Muslims of Crimea on banning these sectarian organizations have been heard" (Ivzhenko 2012). It is questionable, how widely Ablaev's concerns were shared among Crimean Tatars in 2012. However, it is clear that the Russian regime has undeniably been more efficient in blocking extremism and the activity of 'sects', but also religious freedom than Ukraine.

\subsection{Nurdzhular}

In May 2007, the Moscow Koptevo District Court banned as extremist fourteen parts of the Russian translation of the Rislae-I Nur by Said Nursi (1876-196o). The verdict was based on an expert's statement, in which it was explained that the publication attempted "to influence the psyche of the reader subconsciously, using mechanisms of religious belief, i.e. the formation of conscious values and convictions with an irrational basis" (quoted in Fagan 2013: 161). The ban was criticised both in Russia and abroad. Indeed, the court has refused to take into account several statements by Russian scholars of religion and Muslim organizations. In the years that followed, many more of Nursi's publications were banned. In April 2008, the Supreme Court of the Russian Federation banned the Nurdzhular organization for being extremist. Again, the basis for this accusation was widely condemned.

Human rights organizations and Muslim activists have criticised the ban, claiming that there is no evidence of the existence of the Nurdzhular organization in Russia. Those arrested for being members of Nurdzhular, it is claimed, have been detained simply for reading Nursi's works (Ponomarev 2012; Smirnov 2008). Many of these people have denied the accusation, pointing out the absurdity of concluding that reading certain publications is the same as belonging to an organization run by their author (Fagan 2013:159-61). However, the measures taken against Nurdzhular have met with the approval of experts known to support action against Islamic activism in Russia. Silantyev (2007: 439), for example, suggests that the ban is valid by making the erroneous claim 
that both Nurdzhular and Nursi's publications are also banned in Turkey for their extremist tendencies. Reporting on such matters by seemingly neutral news outlets thus creates an image of the prevalence of radical Islamic activity in Russia.

In its denunciation by Muslim leaders and human rights organizations in the media, Nurdzhular is often referred to as an extremist sect. In the Izvestiya article "Sectarians Spied Russia," Nurdzhular is accused of spreading panTurkish ideas in Russia and raising "a generation in Turkic areas in Russia, loyal to Turkey." The same article claims that Nurdzhular is a cover organization for the CIA's operations in Russia (Bulavin 2011). Moreover, a connection to terrorism has been made in the official newspaper of the Russian Government, Rossiiskaya Gazeta (25 April 2007), which stated that "according to the international intelligence, the members of Nurdzhular are connected to the terrorist organization the Grey Wolfs Bozkurtlar," as well as claiming that Nurdzhular books promote the idea of "overthrowing the secular order and replacing it with shariat [sharía]."

\subsection{NORM}

The National Organization of Russian Muslims (Natsional'naya Organizatsiya Russkikh Musul'man, or NORM) was founded in 2004 as an organization aiming to represent and defend the rights of ethnic Russian Muslims. NORM argues that ethnic Russian Muslims should not reject their national traditions and roots upon conversion to Islam. According to Renat Bekkin, the godfather of NORM was Geydar Dzhemal, who, in Soviet times, gathered a group of left-wing and conservative revolutionary intellectuals around him. Dzhemal, whose mother was Russian and father was Azerbaijanian, was a Shīite; remarkably, NORM members include both Sunnīs and Shīites.

From the outset, one of the group's leading ideologists (who would also become its leader) was Vadim Sidorov (Kharun ar-Rusi), who, in addition to being a student of Dzhemal, had a background in Russian ultra-rightist nationalist circles, as did many of the founding members of the organization. Sidorov, along with many other prominent figures within the organization, has flirted with Fascism and has openly admitted his interest in the ideas of traditionalists like Julius Evola and René Guénon. A year after the foundation of NORM, Shì'ite members were expelled from the group and Sidorov fell out with Dzhemal, criticizing his internationalist tendencies.

Initially, both Sidorov and NORM seemed to subscribe to Salafism. Inspired by its contact with the Murabitun World Movement, however, in 2007, NORM announced that it bases its activities on the Maliki madhhab and Șüfism, although it does accept members from other madhhabs (Bekkin 2012: 380-7). 
Only a small percentage of ethnically Russian Muslims belong to NORM. This is either because they do not subscribe to the organization's ideas or because they have never heard about it. After expelling the Shīites, the organization gained some new prominent members, such as Ali Polosin; when NORM begun to take a more critical stand against the state, however, they left. NORM was among the few Muslim groups that openly supported the anti-Putin demonstrations in 2011 and 2012, as well as the Ukrainian Maidan. Sidorov claims that before these events, NORM tried to distance itself from active involvement in opposing the Government, but the oppression of Muslims (and ethnic Russian Muslims in particular) compelled it to abandon its loyalism ("Znachimoe Ottsustvie" 2015).

Oppressive measures against NORM began in St Petersburg in 2013, when several of its members were arrested. The informal leader of the group, Maksim Baidak (Salman Sever), was accused of "justifying terrorism." The charges were based on a blog written by Baidak two years earlier, in which he expressed some understanding of the motives of the Primorskie Partizany, ${ }^{5}$ a criminal group which had attacked and killed several police officers in 2010. Arrests made for the purpose of questioning spread to other cities as well so that, by the end of 2013, the majority of NORM leaders had fled Russia.

NORM has condemned the annexation of Crimea and, in 2014, it founded a new organization, Slavyano-Islamskaya Liga (the Slavic-Islamic League), together with some groups representing ethnic Ukrainian Muslims. Sidorov claims that Russian special services continue to monitor and intimidate people whom they suspect of being connected to NORM. It is because of these threats, Sidorov argues, that the organization has become more closed since the late 20oos. After leaving Russia, leading NORM figures advised all the group's members and friends in Russia to disassociate themselves publicly from the organization (Sila 2015).

NORM has been presented as a sect both in media reports and by rival Muslim organizations. The latter tend to base their claims on the doctrinal nature of NORM. The organization Darul'-Fikr, which also includes some ethnic Russian Muslims, has labeled both the Murabitun World Movement and NORM "misguided sects." They have also accused them of being overly nationalistic and blindly following Western culture, including Western philosophy and discourse, which they see as unnecessary or even harmful for Muslims ("Russkie

5 The Primorskie Partizany had been mistreated by police officers and the case aroused much discussion about police brutality in Russia. Originally, the Primorskie Partizany had no connection with Islam; some of the members have been reported to have converted to Islam, however, during their time in prison. 
musul'mane" 2010; Bekkin 2012: 385-387). In 2007, NORM published a report in response to its accusations of being a sect. Surprisingly, NORM chose to defend the word 'sect' by drawing on the hadith, in which, NORM stated, Muhammad predicted that Islam would be divided into 73 sects. NORM argued, therefore, that all Muslims belong to some sort of 'sect'. Notably, NORM does draw a distinction here between the 'sect' and the 'misguided sect', rejecting the second label (Ar-Rusi 2007).

In the media, accusations of sectarianism made against NORM are usually linked to suspicions about Russian Muslims in general. As in the case of Wahhābism, the threat posed by radical ethnic Russian Muslims seems to be exaggerated in the press. For example, in an interview with Komsomol'skaya Pravda on 6 June 2015, Silantyev argued that if a Slav converted to Islam, there was a 90 percent chance that he or she would end up in a 'radical sect'; he also referenced both Wahhābism and NORM. In another interview, he commented on the role of ethnic Russian Muslims in terrorist activity: "If, earlier, the most criminal sect in our [country] was considered to be the Satanists, which immediately fell into the special category, nowadays, it can be said that radical [ethnic] Russian Muslims have surpassed them in their inclination towards criminality (kriminogennost)" (Svetlova 2011). Some reports describing NORM as a sect refer to a change in the organization's behavior at the end of the 200os. In a 2009 article about ethnic Russian Muslims in the popular newspaper Nezavisimaya Gazeta, it was argued that the adoption of the Maliki madhhab and the election of Sidorov as leader led NORM to "become alien for Russians and for Russian Muslims and turned [it] into a minute pro-Nazi sect" (Mal'tsev 2009).

\subsection{Scholars on the Faizrakhmanisty}

Until recently, there was little scholarly literature on the Faizrakhmanisty. Of the few publications on this topic, some fall more into the category of theological contentions, rather than scholarly analyses. The two publications on the group that are cited most often are 'Unofficial Islam in Tatarstan' (2003) and 'Anti-Islamic Tendencies' (2006) by the scholar and Islamic leader Valiulla Yakupov. Yakupov knew the organization's leader, Faizrakhman Sattarov, very well. Despite his thorough acquaintance with the Islamic tendencies within

6 Interestingly, in this booklet, Yakupov seems to use the terms "unofficial Islam," "nontraditional Islam," and "sect" interchangeably. 
Tatarstan and his scholarly competence, Yakupov's writings on Islam (in particular, his non-official Islamic tendencies) are indicative of his position as a theologian and official in the DUMRT. For example, in his booklet Anti-Islam: About the Sectarian Nature of Wahhābi Reformers (2006), he maintains that there cannot be any real Islam outside the four (Sunnī) madhāhib. According to Yakupov, Wahhābism was created by the British special services in order to cause discordance among Muslims (2006: 5-9). Yakupov also criticises Nurdzhular and reminds his readers that "during the cold war [Said Nursi] did much to discredit our country, factually supporting NATO's plans against the USSR" (2006: 38).

After the Faizrakhmanisty's rise into public consciousness in 2012, another source became widely cited: an online article entitled "Faizrakhmanisty: A Sect of Islamic Origin in Tatarstan in the 21st century" and written by a highly controversial scholar of Islam, Rais Suleimanov (2011) whose claims about the prevalence of radical Islam have been contested by scholars and Muslims alike. ${ }^{7}$ According to Suleimanov, the Faizrakhmanisty represent a "salient example of a totalitarian sect with Islamic origins" (2011). The rector of the Islamic University in Kazan, Rafik Mukhametshin, has also written about the Faizrakhmanisty. Unlike Yakupov (2003) and Suleimanov (2011), who both describe the Faizrakhmanisty in terms of the concept of the 'totalitarian sect', Mukhametshin does not use even the word 'sect'; rather, he refers to the Faizrakhmanisty as a 'group' or 'movement'. In an interview after the raid on the Faizrakhmanisty compound, Mukhametshin explained that, in his view, the Faizrakhmanisty could not be considered an Islamic sect because the group mixes together various Islamic traditions and elements, and also lacks a coherent religious doctrine (Ivanov 2012). The most recent studies of Sattarov and Faizrakhmanisty has been conducted by Renat Bekkin (2018, 2020), who bases his writings in both diligent study of archives and fieldwork material.

\subsection{Faizrakhman Sattarov and His Teachings}

Faizrakhman Sattarov was born in Ufa, the capital of Bashkortostan, in 1929. After compulsory service in the Soviet Army, he had various odd jobs, including one as a janitor. In 1955, he entered the Mir-I'Arab Islamic Madrasa at Bukhara and the Baraq-Khan Madrasa in Tashkent (in the Soviet Union, these were the

7 For example, an eminent Russian scholar of nationalism, Valerii Tishkov, called a report about the threat of ethno-religious conflicts and radical Islam in Povolz'e, published by the Russian Institute for Strategic Research, a provocation. At: http://golosislama.ru/news .php?id=17631. Suleimanov is often argued to have close contact with the Russian security services (see Dzutsati 2014). 
only two institutions which provided higher Islamic learning (Kemper, Motika and Reichmuth 2010: 11). At Tashkent, where Sattarov studied between 1955 and 1964, he was the first Tatar student. After working in a mosque in Kazan, Sattarov was invited by Shamir Khiyaledinov, the leader of the Dukhovnoe Upravlenie Musul'man Evropeiskoi Chasti sssR i Sibiri (DUMECss), to work at his organization. Sattarov's star in the organization began to rise and he was sent to work in mosques in Leningrad, Rostov-on-Donu, and Ufa (Yakupov 2003; Bekkin 2018).

At the beginning of the 1980s, Sattarov began to gather a group of followers and to develop his teachings. According to Yakupov (2003), his alienation from the official DUMECss was his response to being passed over in the DUMECss leadership election in 1980, despite being one of the most suitable applicants for the post, in terms of his mastery of the Islamic tradition. Sattarov himself claimed that, at that time, he had begun to regret cooperating with the Soviet authorities: "The authorities of the state security organizations took me to Islamic countries, where I had to say that 'I do not believe the American slander that believers are harassed in the USSR. We have a total freedom of religion!' That is how I came to be a servant of Satan, a traitor. And when I understood this, I regretted it and began to travel to cities and to preach" (Varsegov 2008). Due to his activities, Sattarov was expelled from the DUMEcss and his followers thus decreased in number (Yakupov 2003).

After the collapse of the Soviet Union, however, Sattarov's scholarship began to be appreciated and the number of people wishing to learn from him grew once more. Paradoxically, many of the future Islamic leaders of Tatarstan, such as Valiulla Yakupov and Ildus Faizov, who later condemned Sattarov, were students of his. Rafik Mukhametshin confirms that "many people came to Faizrakhman-khazrat to learn, because he was educated. In the 1980s, it was impossible to find anyone more educated" (Zavalishina 2013). Sattarov published his religious views in a small publication entitled Iman tamynlary (which translates from the Tatar language as 'The Roots of the Faith'). ${ }^{8}$

In 1992, Sattarov opened a small madrasa in Naberezhnye Chelny, the second largest city in Tatarstan, and also created communities in Ufa and Kazan. In 1996, he settled in Kazan on 700 square meters of land, which he called $d \bar{a} r$ al-Islām or 'the house of Allāh' (gosudarstvo Allakha). This compound, housed in a three-story building, became home to Sattarov and his followers. He was

8 Interestingly, none of the scholars who are discussed in this article refer to this publication, which was Sattarov's only publication. Likewise, it is not available in either the Russian National Library or the State Library, which, between them, should be in possession of everything published in Russia. 
able to register the land officially as a residence for his community and he also obtained land for the construction of a mosque, although the latter was never realised. In the 199os, then, the community was thriving, and functioned in a very democratic manner. According to Yakupov (2003), however a schism appeared in the community when one of its students begun to gain too much influence. When he was expelled from the community, a substantial number of people deserted Sattarov.

At the beginning of the 200os, the community began to become more isolated and to take a more critical stance in relation to the rest of society. The Faizrakhmanisty refused to pay taxes or utility charges, so their water, gas, electricity, and telephone were disconnected by the authorities. The organization's children were kept out of public schools and the members refused to receive any medical treatment. In fact, the community went as far as denying the validity of the Russian state and its laws; the Faizrakhmanisty created their own passports and flag. As the 2ooos went on, however, the authorities began to challenge the organization's activities more and more. Members were banned from a local marketplace where they sold food products, a move which was attributed to their inability to compromise with officials. Equally problematic was the fact that, given that official Islamic organizations refused to acknowledge the Faizrakhmanisty as Muslims, the organization's deceased could not be buried at Islamic burial grounds. Nonetheless, Sattarov was not afraid of presenting his community as being distinct from official Islam in Tatarstan, which left it vulnerable to accusations of sectarianism (Bekkin 2020).

The Faizrakhmanisty consider all other Muslims heretics and therefore do not allow any outsiders into their mosques. Nevertheless, the community has grown slowly; according to the local newspaper Vechernyaya Kazan, in 2002, twenty-two people lived in the compound but by 2012, the number of the followers had increased to nearly seventy (Yudkevich 2012). Whereas in the 198 os, the community attracted many middle-class people, several reporters argue that by the 20oos, most of Sattarov's followers were the uneducated and underprivileged. Many of Sattarov's critics claim that money was one of his main motives for creating the community, suggesting that some of his supporters were pursued for their wealth. However, Sattarov can hardly be accused of seeking a lavish lifestyle, given that he shares the ascetic life of his followers. Moreover, some interviews with community members have indicated that at least some of these people came to the community in order to be saved from poverty and hunger (Varsegov 2008). By the end of 2000s, Sattarov's Parkinson's Disease compelled him to stay in bed and made him unable to continue teaching and preaching. The leadership of the community was entrusted to one of his followers, Gumer Ganiev, who gained the title of emir (Arab. amir). 
It should be noted that the term 'Faizrakhmanisty' has been created by outsiders as a label for the organization. Members of the community called themselves Mu'mins or simply 'true Muslims'. Sattarov refers to the concept of seventy-three branches of Islam, of which only one is the true one. He claims that the end of the world is soon to come and the only ones who will be saved are his followers. He has stated that he receives direct messages from Allāh in his sleep and calls himself a messenger of God. He does not claim to be unique in this respect, however; he suggests that there have been, and will be, other messengers (including women), all of whom will suffer for their faith. In 1976, Sattarov claimed to have received the title narsulla ('Allāh's helper') from God. In 1993, he also claimed the title of rasulalla ('messenger of God'). Critics such as Valiulla Yakupov argue that this change amounts to appropriation of the title of the Prophet, as rasulalla can be interpreted as having such a meaning. ${ }^{9}$ Sattarov has always denied considering himself to be a prophet, however. Indeed, in an interview with the newspaper $N G$-Religii, Sattarov is careful not to break one of the five commands of Islam by disputing that Muhammad was the last prophet. He explains that while a prophet receives instruction directly from Allāh, a messenger's task is to bring more people to faith (Aisin 2007). Apparently, the members of the community also understood this crucial difference; after being raided by the security forces, one member stated: "do not call us sectarians. The messenger is not a prophet, just a messenger. We are not breaking [any laws of] Islam" (Allenovaya 2012). Nevertheless, the Faizrakhmanisty had several ritual practices and hold many beliefs that appear very unorthodox. For instance, according to Sattarov, the true Ka'ba is located on the premises of his community and all of its members, therefore, performing hajj daily (Demidova 20o9).

For the Faizrakhmanisty, the only authority is the Qurann. They deny the validity of various madhhabs and any forms of national Islam, including Tatarism. However, there are distinct nationalist tendencies in Sattarov's teachings, including an emphasis on the 'golden age' of the earliest Tatar state, Volga Bulgaria (c. 700-1238 CE). Sattarov criticises the political and religious elite of Tatarstan for cooperating with Russia-for "shaking their hands." Nevertheless, in another interview, he states that he has nothing against Russians, as long as they stay in their own areas (Varsegov 2008). During the 2000s, Sattarov's attitude toward the Russian state turned more hostile. In an interview in 1998, Sattarov stated that he prefers the state to remain secular, not religious and

9 According to Il'shad Nurmiev's (2012: 136) Dictionary of Islamic Terms (in Russian), (ar) rasulla ( ) means "the Prophet" and rasulullakh means "messenger of God." The dictionary is approved by the Commission of the DUMRF. 
that "citizens should remain loyal and [...] participation in politics is permissible" (Makarov and Mukhametshin 2003: 132). A few years later, the community began to disassociate itself from the state and the surrounding society, which is when Sattarov denied the legitimacy of the Russian Federation. Nevertheless, the Faizrakhmanisty have never expressed any inclination toward revolutionary activity. In the 2000s, the sect ended proselytism in outside society and even Suleimanov (2011) admits that "though not acknowledging the state, they have a loyal attitude towards it. Sattarov does not call his followers to engage in any kind of war."

\subsection{The Raid of August 2011}

Religious control of unofficial Islam tightened up in Tatarstan throughout the 2000 (see International Federation for Human Rights 2009). However, even stricter measures followed the terrorist actions that took place on 19 July 2012: the murder of Valiulla Yakupov, the deputy to the Mufti of Tatarstan, and the assault on the chief Mufti, Ildus Faizov. Immediately after the attacks, the police and special forces began a campaign against Islamic terrorism, within which they made raids on various Islamic organizations, confiscated literature and computers, and arrested up to 6oo people (Mukhetdinov and Khabutdinov 2012: 215-245).

It was as part of this anti-terrorist campaign and the search for the murderers of Yakupov that the raid on the premises of the Faizrakhmanisty took place on 1 August 2012. According to the police, they "received information" that guns might be stored at the compound. As expected, no weapons were found in the raid; instead, the authorities concluded that the premises were unsuitable for habitation and twenty-seven children were taken to a hospital, where they were found to be healthy and returned to their parents. The police confiscated approximately 1,0oo books, including some manuscripts by Sattarov, in order to check them for signs of extremist activity. At first, Sattarov was prosecuted for arbitrariness (samoupravstvo), ${ }^{10}$ but this was later changed to a charge of extremism. Once more, the children were taken from their parents, who were told that they would lose their parental rights unless they left the compound and allowed the children to go public schools and have medical

10 Under the Russian criminal code, this is defined as "the unauthorized commission of actions contrary to the order presented by a law or any other normative legal act, actions whose lawfulness is contested by an organization or individual, if such actions have inflicted substantial harm." See http://www.russian-criminal-code.com/PartII/SectionX/ Chapter32.html. 
treatment. Most of the parents submitted to these demands and only around fifteen members stayed at the compound.

On 25 February 2013, the court of the Sovetskii district of Kazan declared the Faizrakhmanisty an extremist group. The verdict was based mainly on the rights of the citizens and children, which were argued to have been violated due to, for example, being forced to live in isolation, not being allowed to receive medical treatment, and being coerced into religious group. The verdict also referred to the "breaking up of families" on the basis of religious conviction. One of the few defenders of the community was the human rights organization sova Center, which stated: "Despite the fact that the members of the community led an isolated way of life and the theology of the community differed from the traditional Islam, we do not see any grounds for declaring the community extremist and we consider the banning of its activity lawless" ("Obshchina faizrakhmanistov" 2014).

In August 2013, all Sattarov's manuscripts, which were confiscated during the raid, were declared extremist and added to the federal list of banned materials. The manuscript collection contained a variety of materials: mostly handwritten books in the Tatar language but also leaflets, single papers, and a personal letter. The official list gives very cursory information about the material: "No. 61. Grey notebook with writing in Russian and Arabic. No. 77. Papers in format A4, joined with a metal clip" (Zaochnoe 2013a). As is customary in such cases, the verdict was based on the testimony of the experts, who had assessed the material from the viewpoints of linguistics, psychology, and religious studies. These unnamed experts (their names were not included in the proceedings) pronounced that the material was "targeted at transforming the personality of the reader, to change his worldview, values, conviction, and the manners of behavior. Its effects can be isolation from the surrounding world, the destruction of an individual's spiritual, and physiological harmony, [causing] an individual to oppose social structures and norms which have established themselves in the society" (Zaochnoe 2013a). The material was also found to create negative opinions of other religions and promote aggressive behavior toward followers of different faiths. Moreover, the contents of the literature were declared "not to correspond the classic concepts of Islam" (Zaochnoe 2013a).

After the raid, some Faizrakhmanisty members remained at the compound. In November 2013, however, the Sovetskii district court ruled that the Faizrakhmanisty, including the property owners, had lost their right to live in the compound. The verdict stated that: "The religious group represents an isolated community, which lives according to its own internal rules and ordinances, which brings clear threat to societal peace. Moreover, [allowing] these 
citizens to continue living and planning together can create a threat to the security of the Russian Federation. Only enforced dissolution of the group 'Faizrakhmanisty' enables us to secure and effectively protect the rights, prescribed by law, and interests of a non-specified group of people" (Zaochnoe 2013b). In April 2014, the police evicted the last fifteen people from the compound.

\subsection{Media Coverage of the Case}

The story of the raid on the premises of an 'underground sect' spread rapidly not only through the Russian media, but also internationally, both in print and online. The majority of the reports drew a picture of the Faizrakhmanisty as a dangerous sect. Often, this was achieved in subtle ways-for example, by comparing the Faizrakhmanisty with the Christian sect Penzenskie zatvorniki, whose members barricaded themselves underground in 2007 and threatened to burn themselves as they were waiting for the end of the world. Despite the fact that the Faizrakhmanisty had no suicidal inclinations and lived in a house, parallels between the two were drawn (Sokolov 2012). It seems improbable that the police ever seriously suspected that the Faizrakhmanisty had anything to do with terrorism; the statement that the sect's whereabouts was discovered during the investigation into the murder of Yakupov, however, insinuates just that. Moreover, in some newspapers, it was reported that Yakupov had criticised both the Faizrakhmanisty and Sattarov.

The most negative and exaggerated versions of the events and the community seem to have been propagated most efficiently. Outright misinformation was repeated in the Russian and international media. The raid was portrayed as a dramatic finding; many articles used words to the effect that the police had 'discovered' a sect. However, the community was well known to local people - it had been discussed in Russian newspapers before and members of the community had given numerous interviews to the press. Indeed, the Faizrakhmanisty have been under surveillance for years. A newspaper article from 2007 explains that police waiting outside the compound had stated: "They live there quietly and peacefully" (Basilaya 2007). As Rafik Mukhametshin admits, "There have always been Faizrakhmanists [here], which was known to both the law enforcement and social authorities. But, I think, they were afraid to ban them [the Faizrakhmanisty], because it would have caused much controversy. After the [terrorist] events in July, it seems, it was decided to solve this problem, as well" (Zavalishina 2013).

Many newspapers stated that Sattarov had deprived members of all contact with outside world. However, even though such interactions do seem to have 
been limited, other reports indicate that a complete ban on contact was never in force. For example, in 2007, the newspaper Komsomol'skaya Pravda wrote: "as it turned out, the underground-dwellers (zatvorniki) still go outside the gates and have been chatting with the police and the neighbors with pleasure" (Basilya 2007). In 2008, when journalists from Komsomol'skaya Pravda visited the compound, some members of the community told them that they read and respected the newspaper (Varsegov 2008).

The state-run media in Russia had an important role in spreading the news abroad and in forming the dominant image of the community. Perhaps the most dramatic misrepresentation was the claim that many of the children had never seen the light of day, which had no basis in fact. As CNN stated on 10 August, "The state-run newspaper Russia Today said some [children] were born underground and have never seen daylight." An article published in the Daily Mail on 8 August 2012 claimed: "A cruel religious sect kept twenty-seven children locked away in dark and unheated underground cells-some for a decade. The youngsters, aged from one to seventeen, have never seen daylight and have now been rescued from their living hell in Russia." Even less scandal-seeking, more prestigious media offered a similar story. On 9 August, The Guardian wrote: "The digging began about a decade ago, and seventy followers soon moved into an eight-level subterranean labyrinth of cramped cells with no light, heat or ventilation. Children were born. They too lived in the underground cells for many years - until authorities raided the compound last week and freed the twenty-seven sons and daughters of the sect." There were some more balanced articles. On 14 August, Mansur Mirovalev reported in The Huffington Post: "A brief visit inside the compound, which provided shocking headlines around the world when police raided it and seized the children, revealed none of the elaborate underground design described by prosecutors. Nor does a police video showing rooms inside. The father of a cult member, who originally disapproved of his daughter joining the group, said he was able to visit freely and has no complaints about how members live or treat their children."

Having analysed twenty-seven Russian and ten Western media reports on the raid, I have found that members of the community were interviewed in very few cases. Moreover, some of these 'interviews' consisted of just one quoted sentence. ${ }^{11}$ The most frequently quoted persons were police representatives, court officials, and medical professionals. The subject expert quoted

11 The community did not let reporters on to the compound premises, but members did talk with reporters at the gate. 
most often was Rais Suleimanov, who, some Russian sources claimed, had conducted an 'extensive study' on the Faizrakhmanisty. In the material examined for the present chapter, Suleimanov's comments appeared in four Russian and five Western media reports.

A more skeptical attitude toward the authorities can be found in readers' comments on the internet, especially on Islamic websites and Tatarstan media sites. Here, people who knew the community rejected media representations of the Faizrakhmanisty as a dangerous or 'totalitarian' sect. The skeptics targeted both the authorities and the mainstream media. Some commentators noted that the living conditions of the Faizrakhmanisty were not that different from the ways in which a substantial proportion of the Russian population lived in the countryside. In this way, the conservative religious lifestyle of the Faizrakhmanisty was depicted by some as mirroring the reality of Russian society. On Radio Azattyck's website, one reader commented: "What did the parents do differently? Didn't they live like everyone else? Not watching the Olympic [Games] on TV, not drinking beer, not smoking, not wearing miniskirts and so on?" (Andrukhaeva 2012).

On some Islamic sites in particular, the measures taken by the authorities and the representations perpetuated by the media were denounced as being examples of Islamophobia existing in Russian society. This can be seen in quotations like: "I still do not understand why they are called sectarians? Because they look like Muslims, talk like Muslims and behave like Muslims?" (Alishaev 2012). On a Tatarstani news portal, a reader's comment revealed the skepticism toward the authorities' fight against Islamic terrorism: "Something very strange here ... As soon as there is a terrorist action, our brave 'internal [surveillance] authorities' begin to intimidate this half-crazy Faizrakhmanisty. It gives an impression that, as the joke goes, they [special services] are not looking for the key where they lost it, but in there, where there is more light" (Kazanskie sektanty 2013).

An examination of labeling phenomena in the Russian media indicates that the term 'sect' is used in the construction of images of social problems. Moreover, it is chosen specifically to refer to social groups of Islamic dissent that are figured as posing difficulties within society. As we have seen, it is easy to find links between the media label 'sect' and legislative measures taken against religious organizations such as the Wahhābists, Nurdzhular, and the Faizrakhmanisty. 
When coupled with the broadening of the category of 'extremism' in Russian court decisions, accusations of sectarianism by the media and depictions of various groups' activities as suspicious can be devastating to religious communities.

In the media, the Faizrakhmanisty have been criticised on various grounds: for distorting Islam, practicing religious fundamentalism, violating the rights of children, brainwashing people, and exploiting people to satisfy the leader's so-called greed and power hunger. These accusations mirror the characteristics of the 'totalitarian sect' elaborated typically in Russian discussions from the 199os onward. The accusations are not completely unfounded but it is evident from an analysis of media reports that the Faizrakhmanisty have been constructed as a typical 'totalitarian sect' through selective reporting. This is symptomatic, in part, of the fact that the person referred to most often as a scholar of the topic, Rais Suleimanov, has clear biases, preferences, and political ambitions, which can be detected in his statements about the Faizrakhmanisty. It can be concluded that a lack of knowledge about Islam led to many Russian and Western media outlets simply repeating the most dramatic claims that were made about the case by Suleimanov and others, even though they were inaccurate.

The case of the Faizrakhmanisty reflects currents in the flow of ideas not just in Russia, but in many Western countries, as well. The increasing tendency toward discussing Islamic minorities within the framework of security invites authorities to have dismissive attitudes regarding non-traditional religions and newer communities. Ironically, this securitization creates pressure for uniformity within Muslim organizations, leading to the rejection of religious pluralism and constraints on the freedom of religion. It is thus that, in Russia, depictions of the Faizrakhmanisty, arguments about 'totalitarian sects', and Islamic extremism have been elided, blurring the definitions of and links between all three.

\section{References}

Aisin, K. 2007. “Sem' sotok dlya 'partii Allakha." NG-RELIGII, 19 December.

Aitamurto, K. 2015. "The approved and the disapproved Islam in Russia." In G. Simons and D. Westerlund eds, Religion, Politics and Nation-Building in Post-Communist Countries. Farnham: Ashgate, 99-116.

Aitamurto, K. and A. Gaidukov. 2018. "The Diversification of the Muslim Community in St. Petersburg in the 2010s." Journal of Religion in Europe. 11:2-3, 222-247. 
Alishaev, M. 2012. “'Faizrakhmanistam' trebuyetsya glubokaya religioznaya reabilitatsiya-Mukhametov." Ansar.ru, 10 August. At http://www.ansar.ru/analyt ics/fajzrahmanistam-trebuetsya-glubokaya-religioznaya-reabilitaciya-muhametov. Accessed 10/08/2020.

Allenovaya, O. 2012. "Ostorozhno, vera zakryvaetsya." Kommersant.ru, 20 August. At http://www.kommersant.ru/doc/2001063. Accessed 10/o8/2020.

Andrukhaeva, A. 2012. "V Tatarstane nachali bor'bu s radikal'nym islamom." Radio Azattyk, 22 May. At http://rus.azattyq.org/content/muslims-sekta-satarov-faizov -yakupov-tatarstan/24672448.html. Accessed 10/o8/2020.

Ar-Rusi, K. 2007. "Apologiya sektanstva." Blog NORM: Soobshchestvo Russkikh Musul'man, 14 June. At http://norm-blog.livejournal.com/123og.html. Accessed O1/12/2015.

Baran, E.B. 2006. "Negotiating the Limits of Religious Pluralism in Post-Soviet Russia: The Anti Cult Movement in the Russian Orthodox Church, 1990-2004." Russian Review. 65:4, 637-656.

Barker, E. 2010. "The cult as a social problem." In T. Hjelm ed., Religion and Social Problems. New York: Routledge, 198-212.

Basilaya, V. 2007. "A veto vremya." Komsomol'skaya Pravda, 26 November.

Bekkin, R. 2012. "Russian Muslims: A misguided sect, or the vanguard Of the Russian umma?" In A.K. Bustanov and M. Kemper eds, Islamic Authority And the Russian Language: Studies On Texts From European Russia, the North Caucasus And West Siberia. Amsterdam: Pegasus, 361-401.

Bekkin, R. 2018. ''Ukorotit' khvost' nezakonnykh religioznykh deyatelei' Ob ideinoi evolyutsii vzglyadov Faizrakhmana Sattarova na rol' 'offitsial'nogo dukhovenstva' v zhizni musul'man Rossii." Gosudarstvo, Religiya, Tserkov. 4:36, 277-323.

Bekkin, R. 2020. "The Faizrakhmanists of the Volga Region as a Religious Community Opposing 'Traditional Islam'. In R. Bekkin ed., The Concept of Traditional Islam in Russia. Sarajevo: cNs, 135-159.

Bukharaev, R. 1996. "Islam in Russia: Crisis of leadership." Religion, State and Society. $24: 2-3,167-182$.

Bulavin, V. 2011. “Sektanty shpionili za Rossiei." Izvestiya, 31 March.

Bustanov, A.K. and M. Kemper. 2013. "Valiulla Iakupov's Tatar Islamic Traditionalism.” Asiatische Studien/Études Asiatiques. 67:3, 809-835.

Crews, R.D. 20o9. For Prophet and Tsar. Islam and Empire in Russia and Central Asia. Cambridge, MA and London: Harvard University Press.

Crews, R.D. 2014. "Moscow and the mosque: co-opting Muslims in Putin's Russia." Foreign Affairs. 93:2, 125-134.

Dannreuther, R. 2010. “Approaches to Islam and Islamism." In R. Dannreuther and L. March eds, Russia and Islam: State, Society and Radicalism. London and New York: Routledge, 9-25. 
Demidova, E. 2009. "Faizrakhmanisty—istinnye syny Allakha." Religio.ru, 19 December. At http://religio.ru/photo/2897. Accessed o1/12/2015.

Dzutsati, V. 2014. "Analyst from Tatarstan asserts that the West wants to destabilize the Republic using Islamists." Eurasia Daily Monitor, 29 October. At https://jamestown .org/program/analyst-from-tatarstan-asserts-that-the-west-wants-to-destabilize -the-republic-using-islamists-2/\#.VtQofkanFeg. Accessed 10/o8/202O.

Fagan, G. 2013. Believing in Russia-Religious Policy after Communism. London: Routledge.

Ignatenko, A. 2003. "Raskolotaya umma v ozhidanii sudnogo dnya." Otechestvennye Zapiski. 5:14.

International Federation for Human Rights. 2009. A Society Under Control: Misuse Of The Fight Against Terrorism And Extremism In Russia. At http://www.refworld.org/ docid/4a8424152f.html. Accessed 10/08/2020.

Ivanov, A. 2012. "Faizrakhmanisty trebuyut vernut' im detrei i knigi." 116.ru, 12 August. At http://116.ru/text/news/553447.html. Accessed 10/o8/2020.

Ivzhenko, T. 2012. “'Nevinnost' musul'man' doshla do Kryma." Izvestiya, 27 September.

“Kazanskie sektanty sobyrayutsya v rai." 2019. Bezformata, 11 January (originally published at Intertat.Ru, 22 November 2013). At https://kazan.bezformata.com/list news/kazanskie-sektanti-sobirayutsya-v-raj/15649908/. Accessed 10/o8/2020.

Kemper, M., R. Motika, and S. Reichmuth. 2010. “Introduction.” In M. Kemper, R. Motika, and S. Reichmuth eds, Islamic Education in the Soviet Union and its Successor States. Milton Park: Routledge, 1-20.

Kemper, M. 2012. "Mufti Ravil' Gainutdin: The Translation of Islam into a Language of Patriotism and Humanism." In A.K. Bustanov and M. Kemper eds, Islamic Authority and the Russian Language: Studies on Texts from European Russia, the North Caucasus, and West Siberia. Amsterdam: Pegasus, 105-141.

Khizrieva, G. 2011. "Ali Vyatcheslav Polosin: 'Prestupnoe sektanstvo nikogda ne stanet normoi zhizni!"” Islamdag.ru, 4 April. At http://islamdag.ru/analitika/7352. Accessed 10/08/2020.

Kovalskaya, K. 2017. "Nationalism and Religion in the Discourse of Russia's 'Critical experts of Islam." Islam and Christian-Muslim Relations. 28:2, 141-161.

Ledovskikh, M.A., ed. 2013. Ostorozhno, ekstremizm! Analiz zakonodatel'stva o protivodeistvii ekstremistskoi deyatel'nosti i praktiki ego primereniya. Voronezh: Tsentr zashchity prav SMI.

Makarov, D. and R. Mukhametshin. 2003. "Official and unofficial Islam." In H. Pilkington and G. Yemelianova eds, Islam in Post-Soviet Russia: Public and Private Faces. London: Routledge, 117-163.

Malashenko, A. 2007. Islam dlya Rossii. Moskva: Rosspen.

Malashenko, A. 2013. "The dynamics of Russian Islam." Moscow Carnegie Center, 1 February. At https://carnegie.ru/publications/?fa=50811. Accessed 10/08/2020. 
Mamirgov, Murat Zaudovich. 2007. Kniga islamskikh sekt $i$ verouchenii. Moscow: Televideokampaniya "Islamskii Mir."

Mukhametov, A.R. 2015. "Adaptsiya ili otchuzhdenie? Formirovanie grazhdanskoi identichnosti rossiiskikh musul'man." Ansar.ru, 14 May. At http://www.ansar.ru/ analytics/2015/05/14/59159. Accessed 10/08/2020.

Mukhametshin, R. 2003. Tatary i Islam v XX veke. (Islamv obshchestvennoi zhizni tatar i Tatarstana). Kazan: Fen.

Mukhametshin, R. 2005. Islam v obshchestvennoi ipoliticheskoi zhizni tatar i Tatarstana $v X X$ veke. Kazan.

Mukhetdinov, D.V. and A. Yu Khabutdinov. 2012. Istoriya dukhovnykh upravlenii musul'man Rossii v XVIII-XXI vekakh. Nizhnii Novgorod: NNGU im. N.I. Lobacheskogo.

Nurmiev, I. 2012. Slovar Islamskikh Ponyatii i Slov. Moscow: Novyi Svet.

"Obshchina faizrakhmanistov v Kazani dobavlena v Federal'noi sisok ekstremistskikh organizatsii." 2014. SOVA Center, 11 March. At http://www.sova-center.ru/racism -xenophobia/news/counteraction/2014/o3/d29115/. Accessed 10/o8/2020.

Ponomarev, V. 2012. Rossiiskie spetssluzby protiv 'risale-i nur': 2001-2012. Moscow: Memorial.

"Rab Lampy." 2005. Moskovskii Komsomolets (Samara), 14 December.

"Russkie musul'mane protiv 'NORM'." 2010. Darul'-Fikr.ru, 3 May. At http://darulfikr.ru/ russian_muslims_against_NORM. Accessed o1/12/2015.

Shterin, M. and J.T. Richardson. 20oo. "Effects of the Western Anti-Cult Movement on Development of Laws Concerning Religion in Post-Communist Russia." Journal of Church and State. 42:2, 247-271.

Shterin, M. and D. Dubrovsky. 2019. "Academic Expertise and Anti-Extremism Litigation in Russia: Focusing on Minority Religions." The Soviet and Post-Soviet Review. 46:2, $211-236$.

Silantyev, R. 2007. Noveishaya istoriya islamskogo soobshchestva Rossii. Moscow: IKhTIOS.

Smirnov, M. 2008. “Ombudsmen upolnomochen zayavit'...." Nezavisimaya GazetaNG Religii, 4 June.

Sokolov, A. 2012. "Khalifat na 7 sotakh." Kazanweek, 4 August. At http://kazanweek.ru/ article/4623/. Accessed 10/08/2020.

Suleimanov, R. 2011. "Faizrakhmanisty: sekta islamskogo proishozhdeniya v Tatarstane v nachale XXI veka." Russkaya Narodnaya Liniya, 15 November 2015 At https:// ruskline.ru/analitika/2015/12/o6/fajzrahmanisty. Accessed 12/o8/2020.

Suleimanov, R. 2015. "Faizrachmanists." Russkaya Narodnaya Liniya, 5 November. At https://ruskline.ru/analitika/2015/12/06/fajzrahmanisty/. Accessed 10/08/2020.

Suleimanov, R. 2012. "'Arabskaya revolutsiya' v Tatarstane: islamskie fundamentalisty v regional'noi politike." Etnoreligioznye issledovaniya v Povolzhe, 6 August. At http:// www.kazan-center.ru/osnovnye-razdely/14/302/. Accessed 10/o8/2020. 
Svetlova, E. 2011. "Islam slavyanskoi natsional'nosti." Moskovskii Komsomolets, 8 February.

Varsegov, N. 2008. "Musul'mane-zatvorniki zhdut kontsa sveta, kak i penzenskie sektanty." Komsomol'skaya Pravda, 5 March.

Verkhovskii, A. 2006. "Yavlyaetsya li Khizb ut-Takhrir ekstremistskoi organizatsiei?" SOVA Center, 10 April. At http://www.sova-center.ru/religion/publications/2005/10/ d6o36. Accessed 10/o8/2020.

Verkhovsky, A. 2010. "Russian Approaches to Extremism, Nationalism and Religion." In R. Dannreuther and L. March eds, Russia and Islam. State, Society and Radicalism. London: Routledge, 26-43.

Yakupov, V. 2003. Neofitsial'nyi Islam v Tatarstane: Dvizheniya, teheniya, sekty. Kazan: Iman.

Yakupov, V. 2006. Anti-Islam (o raskol'nicheskoi sushnosti vakhkhabitov-reformatorov). Kazan: Iman.

Yemelianova, G. 2003. "Russia's Umma and its Muftis." Religion, State \& Society. 31:2, 139-150.

Yudkevich, M. 2012. "Sektanty ili zhertvy epidemii?” Vechernyaya Kazan, 4 September.

Yusin, M. 2003. "Trudnaya missiya printsa Abdally." Izvestiya, 4 September.

Zaochnoreshenie imenem Rossiskoi Federatsii. 2013a. Delo No. 2-140o/13, 12 August. Sovetskii raionnyi sud g. Kazani Respubliki Tatarstana. At http://sovetsky.tat.sudrf .ru/. Accessed 10/08/2020.

Zaochnoreshenie imenem Rossiskoi Federatsii. 2013b. Delo No. 2-8657/13, 18 November. Sovetskii raionnyi sud g. Kazani Respubliki Tatarstana. At http://sovetsky.tat.sudrf .ru/. Accessed 10/08/2020.

Zavalishina, T. 2013. "Rafik Mukhametshin: 'Poyavlenie novogo muftiya nikogda ne byvaet sluchainym, ego lichnost'—zerkalo nashikh problem.” Biznes-online, 3o March. At http://www.business-gazeta.ru/article/77068/. Accessed 10/o8/2020.

“Znachimoe Ottsustvie." 2015. Sila. Slavyano-Islamskaya Liga, 12 June. At http://slavic -islam.info/ru/content/1212. Accessed o1/12/2015. 